\title{
TUDOMÁNY HATÁROK NÉLKÜL
}

A Nemzeti Kutatási, Fejlesztési és Innovációs Hivatal küldetése a kutatás-fejlesztés és az innováció kormányzati koordinációja. Ehhez nélkülözhetetlen a rendelkezésre álló források célszerű, átlátható és értékteremtő felhasználása, a vállalkozások, egyetemek és kutatóintézmények közötti aktív tudástranszfer hatékony ösztönzése. Nemzeti összefogásban, erőforrásaink fókuszálásával olyan innovációs ökoszisztémát tudunk építeni, amely kiemelkedő tudományos eredmények és piacvezérelt innovációk elérését teszi lehetővé, ezáltal a teljes magyarság érdekeit szolgálja.

Az innovációs ökoszisztéma fenntartható fejlesztésére irányuló intézkedéseink nem korlátozódhatnak az anyaországon belüli szereplőkre. Magyarország kormánya hosszú évek óta erkölcsi kötelességként, egyszersmind óriási lehetőségként tekint a határon túli kétmilliós magyarsággal való kapcsolattartásra. Ez a kötődés korántsem egyoldalú: a magyarságon belüli tudásáramlás nem ismer határokat és irányokat. Számtalan esetben a határon túli magyarok tudása gazdagította a magyarországi fejlesztéseket, projekteket. Ahogy a kötet címe találóan fogalmaz, a tudományt nem lehet országhatárok közé zárni. Fontos üzenet ez 2020-ban, amikor a trianoni döntés századik évfordulójára emlékezünk. Annak idején a magyarság egységét szétaprózták, a magyar közösség alkotóerejét visszavetették. Ma nekünk kell mindent megtennünk, hogy ezt a történelmi tragédiát a magunk eszközeivel korrigáljuk, és a magyarság - határoktól függetlenül - újra kibontakoztathassa képességeit a tudomány és az innováció területén is.

Az innováció legtermészetesebb táptalaja a megszerzett tudás lehet. Tudás azonban nincs sem tanulás, sem kutatás nélkül. Ezekhez országszerte és a határon túl is korszerű tudásbázisok, elhivatott kutatók és oktatók, jól kiépített kutatási infrastruktúra, ösztönző pályázati rendszerek szükségesek. Ezek együtt megteremtik a lehetőséget, hogy kutatóink, oktatóink, tehetséges fiataljaink mindenhol a helyükön érezzék magukat, hogy saját múltjuk és identitásuk megőrzésével vehessenek részt újító, innovatív kezdeményezésekben, sőt bekapcsolódhassanak nemzetközi projektekbe is.

Hivatalunk 2020-ban immár második alkalommal nyújt támogatást, hogy a határon túli magyar intézmények is hozzáférhessenek a tanuláshoz és a kutatáshoz nélkülözhetetlen magyar nyelvű e-könyves adatbázisokhoz. A projekt első szakaszának kedvező 
tapasztalatai alapján 2020-ban még több intézményt tudunk bevonni, és immár 8200 e-könyv válik elérhetővé a Kárpát-medence valamennyi magyarlakta régiójában. Az Elektronikus Információszolgáltatás Nemzeti Program példaértékű lehet sokak számára: ez a kezdeményezés a magyarság egészének biztosít alapvető segítséget a tudás megszerzésében. Olyan lehetőséget ad, amely aktív, sokoldalú együttmúködést épít az intézmények között, amely a tapasztalatok megosztását, a személyes kapcsolatok kiépítését, az innovációs képességek fejlesztését minden résztvevő számára elérhetővé teszi.

Meggyőződésem, hogy az e-könyv - mint a digitális világ egyik nagy innovációja egyáltalán nem a hagyományos könyv ellensége. Utóbbinak is megvan és még sokáig megmarad a létjogosultsága. Az e-könyv jelentősége abban áll, hogy minden eddiginél szélesebb körben teremt új lehetőséget a tudáshoz való hozzáférésre. Hogy milyen tartalékok rejlenek az e-könyvek és az online adatbázisok világában, annak szemléletes példáját láthattunk a koronavírus okozta szükséghelyzetben. Többek közt ezek tették lehetővé, hogy az oktatási intézmények szinte egyik pillanatról a másikra átálljanak a távoktatásra és az online tanrendre. Büszke vagyok rá, hogy ebben a nehéz időszakban a Nemzeti Kutatási, Fejlesztési és Innovációs Hivatal támogatása is segítette a magyar oktatókat és hallgatókat a tudás biztonságos átadásában és elsajátításában. Nem kell nagy jóstehetség, hogy lássuk: a jövőben minden bizonnyal még inkább nő majd az online források használata iránti igény.

Biztos vagyok benne, hogy e hiánypótló program folytatása tovább mélyíti a szakmai együttmúködéseket, sikeresen segítve a tudásáramlást és a határokon is átnyúló magyar innovációs ökoszisztéma fejlődését.

Dr. Birkner Zoltán

a Nemzeti Kutatási, Fejlesztési és Innovációs Hivatal elnöke 